\title{
Providing Online Learning Situations for In-Service Mathematics Teachers' External Transposition Knowledge During COVID-19 Pandemic: Case of Indonesia
}

\author{
Marfuah Marfuah ${ }^{1,2,3}$, Didi Suryadi ${ }^{1,3}$, Turmudi Turmudi ${ }^{1}$ and Muhamad Galang Isnawan ${ }^{4}$ \\ ${ }^{1}$ Universitas Pendidikan Indonesia, Bandung, Indonesia \\ ${ }^{2}$ PPPPTK Matematika, Sleman, Indonesia \\ ${ }^{3}$ PUI-PT PUSBANGDDRINDO, Bandung, Indonesia \\ ${ }^{4}$ Universitas Nahdlatul Wathan, Mataram, Indonesia \\ marfuah@kemdikbud.go.id \\ ddsuryadi1@gmail.com \\ turmudi@upi.edu \\ galangisna19@gmail.com
}

\begin{abstract}
Updating mastery of mathematics scholarly knowledge is vital for mathematics teachers' professional development in Indonesia. External transposition refers to the transposition of mathematics scholarly knowledge to the school curriculum. During the COVID-19 pandemic, online learning becomes the primary strategy for strengthening the external transposition knowledge of mathematics teachers in Indonesia. This study aims to describe the process of providing online learning situations in lifting the in-service mathematics teachers' external transposition knowledge during the COVID-19 pandemic. The online learning involved 57 in-service high school mathematics teachers in Indonesia as participants. The scholarly knowledge to be delivered was the visualization of matrix multiplication. This qualitative study is a didactical design research that includes a prospective learning situation analysis, a meta-technopedadidactic analysis, and a retrospective analysis. In the prospective learning situation, the solutions for re-situating face-to-face learning to online learning were disclosed. Moodle was used as the Learning Management System, and GeoGebra Classroom was used as the Task Response System. A meta-technopedadidactic is an educator's ability to comprehensively analyze pedagogic interaction, didactic interaction, and didactic pedagogy anticipation in using technology in a learning situation. The finding in the meta-technopedadidactic analysis showed the role of technology as a visualization tool in online learning, evidence of participants' external didactic transposition, constraints, and collaboration in learning. Finally, the retrospective analysis suggested some future improvements for better online learning situations. This study contributes to the comprehensive organization of e-learning courses in Indonesia for mathematics teachers' professional development based on pedagogic interaction, didactic interaction, and didactic pedagogy anticipation in the use of technology. Despite some of the study's limitations, the findings have the potential to be an advantage for the long-term sustainability of e-learning as a new norm for teachers' professional development programs, rather than just a foreshadowing of the pandemic.
\end{abstract}

Keywords: online learning situation, teachers' professional development, external didactic transposition, didactical design research, Moodle, GeoGebra Classroom

\section{Introduction}

Due to the COVID-19 pandemic, education in Indonesia is shifting to online learning to enforce health protocols, a scenario that almost every country faces. Several survey studies reveal the difficulties faced by Indonesian educators in reacting to the abrupt shift in the school system during the pandemic (Fauzi, et al., 2021; Garad, AlAnsi, and Qamari, 2021). Additionally, many authors survey in-service mathematics teachers in Indonesia and show their perspectives on the challenges of adopting online learning in their mathematics classrooms during the pandemic (Mailizar, et al., 2020; Azhari and Fajri, 2021). However, little information about the practice of inservice mathematics teachers' professional development (PD) in Indonesia during the COVID-19 pandemic.

Before the pandemic, Indonesia already has a long-run agenda of innovative mathematics teachers' PD programs (Kusumah and Nurhasanah, 2017; Sumaryanta, et al., 2018). As an archipelago nation with a large population of mathematics teachers, online learning has become an alternate strategy in Indonesia that complements faceto-face in-service mathematics teachers' PD (Marfuah, 2017; Sumaryanta, et al., 2018). Due to the COVID-19 pandemic, online learning become inevitable as the primary strategy for mathematics teachers' PD in Indonesia.

The outcome of the national assessment, which was conducted in batches from 2015 to 2018, is one of the pillars of in-service mathematics teachers' PD strategies in Indonesia. This outcome shows the urgency of a follow-up program for strengthening teachers in mastering professional competencies and pedagogical competencies (Sumaryanta, et al., 2018). Professional competencies cover mastering mathematics knowledge 
and technology. While pedagogy competencies cover mastering curriculum knowledge, learning theory, developing learning instruction, and managing the classroom. According to Sumaryanta, et al. (2018), as a followup program, mathematics teachers' PD in Indonesia is organized based on courses that differentiate mastering mathematics knowledge and pedagogy competencies to be delivered.

Aside from enhancing mathematics and pedagogical competencies, we identify another issue that requires attention in Indonesian mathematics teachers' PD, which is how the PD program in Indonesia can aid teachers in connecting the mathematics they learned in higher education and the mathematics required by the curriculum. The discontinuity between the mathematics that teachers learn during pre-service and the mathematics that is teachers' responsibility in the school curriculum is a gap that must be followed up on mathematics teachers' PD (Dreher, et al., 2018; Kilpatrick, 2019). The in-service mathematics teachers have complicated responsibilities (Herbst and Chazan, 2020), so their mastery of mathematics scholarly knowledge may shift due to their focus on the duties. As teachers concentrate on their in-service duties at school, at the same time, the development of technology and mathematics knowledge is advancing rapidly from what teachers have learned in their pre-service education. So, it is natural to require teachers to upgrade their competencies.

Switching between institutions can create gaps in mathematical knowledge, as evidenced by Basitere and Ivala (2015). The discontinuity can be explained by the Theory of Didactic Transposition (Chevallard, 2019; Chevallard and Bosch, 2020). According to the theory, mathematical knowledge adapts in the institution that produces it. Those institutions are mathematicians, curriculum experts, teachers, and students. The theory implies that teachers' knowledge should cover: scholarly knowledge, curriculum knowledge, taught knowledge, students' learned knowledge, and the transposition between the first four. There are two main transposition stages: external and internal didactic transposition (Bosch, et al., 2021). External transposition refers to the transposition of scholarly knowledge to the school curriculum. Correspondingly, internal transposition refers to the transposition of taught knowledge by teachers to students' learned knowledge. Thus, the transposition knowledge connects the blocks of knowledge that the mathematics teaching profession requires. Hence, the importance of transposition knowledge for mathematics teachers is not about acquiring advanced mathematics but more about analyzing the dynamics of mathematical knowledge multi-dimensionally and coherently, culminating in how students learn mathematics. Furthermore, transposition knowledge values teacher's autonomy as a profession that has a central role in bridging mathematics knowledge and curriculum knowledge, not just accepting it as the policy of external stakeholders.

Given the significance of transposition knowledge for mathematics teachers and the COVID-19 pandemic situation, this study proposed online learning as a solution to lift mathematics teachers' transposition knowledge in Indonesia. The strength of online learning lies in its flexibility, connectivity, and convenience in studying (Kynigos and Kalogeria, 2012; Lamanauskas and Makarskaitė-Petkevičienè, 2021). One of the key ideas to get through the COVID-19 crisis is that the education system should provide digital open educational access that supports the teaching profession (UNESCO, 2020). Hence, this study aims to describe the process of providing online learning situations in lifting the in-service mathematics teachers' external transposition knowledge. We limited our discussion on constructing external transposition knowledge of matrix multiplication. The following are the guiding research questions: how was the process of designing the online learning situation in facilitating in-service mathematics teachers in lifting their external transposition knowledge of matrix multiplication; how was the implementation; and what should be improved for future implementation? To address those research questions, the following section will provide a literature review on the online learning environment from the perspective of a didactic system.

\section{Didactical System in Online Learning Environment}

Providing mathematics learning situation is about vision on a multidimensional didactic system consisting of teachers' roles, students' needs, specific mathematics content, and learning environment (milieu) (Schoenfeld, 2012 , p. 588). Milieu contains all objects or materials in the didactic system that students interact with to acquire knowledge. Additionally, a milieu can include devices and digital resources that students interact with (Joubert, 2017). The didactic system includes the interaction between teachers and students (pedagogy interaction/PI), the interaction between mathematics content and students (didactic interaction/DI), and the anticipation of didactic and pedagogy that teachers prepare to teach specific mathematics content (Didactic Pedagogy Anticipation/DPA) (Kansanen, 2003; Suryadi, 2013). A meta-pedadidactic is the educator's ability to comprehensively analyze pedagogy interaction, didactic interaction, and didactic pedagogy anticipation in a learning situation (Suryadi, 2013). 


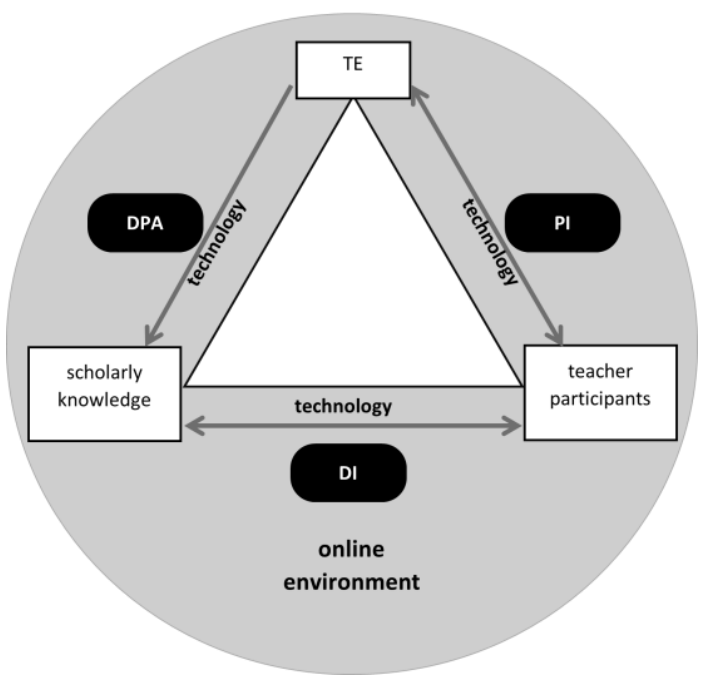

Figure 1: The use of technology in the didactic system

The rapid development of technology expands to the issue of technology integration into didactic mathematics systems (Ruthven, 2012; Cao, et al., 2021). The situation in online learning is undoubtedly different from the situation in face-to-face learning because of the difference in the milieu. Hence, a meta-pedadidactic should be adapted into a meta-technopedadidactic, an educators' ability to comprehensively analyze pedagogic interaction, didactic interaction, and didactic pedagogy anticipation in the use of technology in a learning situation. In this study, the didactic system components are teacher educator (TE), scholarly knowledge about matrix multiplication, and teacher participants, using technology to mediate the DI, PI, and DPA (Figure 1).

The interaction between didactic system components to obtain mathematical knowledge underlies the formation of a learning situation. In the didactic system, Brousseau (2002) defines the learning situation as a series of situations of action, formulation, validation, and institutionalization. Brousseau and Warfield (2020) also write that the learning situation consists of 1) Situation of Devolution, 2) Mathematical Situation, and 3) Situation of Institutionalization. In a Situation of Devolution, the educator explains course objectives, rules and introduces the mathematics problem. Then in a Mathematical Situation, learners perform mathematical activities (our case is matrix multiplication activity), actively make predictions, conduct self-exploration, interact with the milieu, make decisions about mathematical concepts, communicate, and self-validate their decisions. In a Situation of Institutionalization, the participants believe the knowledge is an introspective action on their experience as a learner. Here the educator has a role in preserving participants' knowledge from unexpected deflection and completing knowledge links that have not been covered in previous mathematics situations.

Strengthening teachers' knowledge through online PD courses has become an interest of policymakers, researchers, and educators in various countries (Gómez-Blancarte, et al., 2019; Joubert, Callaghan, and Engelbrecht, 2020; Martínez, et al., 2020; Pölzl-Stefanec, 2021). This research is critical because understanding the learning situation is about more than just the learner's learning outcomes; it is also about understanding the conditions and constraints of the learning system that promote or hinder learning and how the system can be improved for the long-term sustainability of mathematics teachers' PD in Indonesia. Furthermore, substantial consideration should be highlighted to online learning technologies as evidence of implementing new norms in mathematics teachers' PD.

\section{Methods}

\subsection{Didactical Design Research for an online environment}

This qualitative research is didactical design research (DDR). Since 2010, Indonesia has led the development and dissemination of DDR (Rudi, Suryadi, and Rosjanuardi, 2020). DDR's philosophy is to provide active learning situations to construct learners' ways of thinking and ways of understanding mathematics knowledge. The core of DDR is how educators explore the reality in the context of the mathematics classroom underlying the change and reflection of learning (Turmudi, et al., 2014; Suryadi, 2019). Here, DDR implements a hermeneutic phenomenology (Ricoeur, 2016) that combines the narrative of experience and the interpretation of experience in the use of technology (Reijers and Coeckelbergh, 2020). This research paradigm is interpretive and transformative (Guba and Lincoln, 2005; Creswell and Creswell, 2018; Suryadi, 2019), where the authors 
designed, developed, implemented, analyzed the realities and reflected on learning. DDR is a series of processes in designing learning situations in a didactic system, including analysis of prospective learning situations, analysis of meta-pedadidactic, and retrospective analysis (Fuadiah, Suryadi, and Turmudi, 2019; Rudi, Suryadi, and Rosjanuardi, 2020). This study demonstrates how DDR is transforming due to the COVID-19 pandemic. To our knowledge, this is the first DDR study in Indonesia that discusses learning situations in a fully online mathematics classroom with in-service teachers as learners. As a result, the DDR series in this study consists of the analysis of the prospective learning situation, analysis of meta-technopedadidactic, and retrospective analysis.

- Analysis of the prospective learning situation

First, the authors analyzed scholarly knowledge using the didactic transposition perspective to develop the reference epistemology knowledge (Chevallard and Bosch, 2020). The authors also analyzed the pedagogical interactions that will be employed to develop the online learning situation. Second, the results of the scholarly knowledge analysis and pedagogy analysis were then presented as a learning situation design. This design included technological analysis to support each phase of the learning situation and the anticipation. Focus Group Discussion (FGD) was then conducted, inviting all of the authors, three mathematics teacher educators (widyaiswara), and two experienced teachers for validating our design externally. The results of the FGD became our object of revision.

- Analysis of meta-technopedadidactic

The design was implemented in the course, and the authors comprehensively analyzed the aspects of technology, pedagogy, and didactic. The analysis focused on how the providing learning situation can facilitate participants' transposition knowledge of matrix multiplication.

- Retrospective analysis

The retrospective analysis was conducted based on the gap between the analysis of meta-technopedadidactic and the prospective learning situation analysis. The authors also reflected on how the system can be improved for future mathematics teachers' PD directions. The retrospective analysis also serves as internal validation by researchers (Creswell and Creswell, 2018).

Thus, we employed this series of prospective learning situation analysis, meta-technopedadidactic analysis, and retrospective analysis to address each of the three research questions we set earlier.

\subsection{Course setting and Participants}

The course was online asynchronous learning held at http://p4tkmatematika.kemdikbud.go.id/ett/. Despite the common opinion that underestimated the potential of asynchronous learning in an online environment, asynchronous learning has benefits that teachers were more flexible in managing their time for learning (Koutsabasis, et al., 2011; Kynigos and Kalogeria, 2012), especially during the COVID-19 pandemic. Asynchronous learning contributes positively to learners' learning achievement (Corfman and Beck, 2019; Galikyan and Admiraal, 2019).

All the authors contributed to all stages of the research, and the first author acted as the TE. The participants were 57 mathematics teachers from Indonesian high schools. Participants voluntarily registered through open recruitment, valuing teachers' autonomy and flexibility to engage in mathematics teachers' PD (UNESCO, 2020). Several considerations were used to select applicants: 1) geographical proportions, 2) evidence of statements about the ease of Internet access in their area, 3) evidence of statements about their willingness to participate fully asynchronously, 4) evidence of principal support, and 5) at least has a bachelor's degree in mathematics or mathematics education. As for the first, geographical proportions were taken into account to ensure equity of access to professional development and future dissemination throughout all regions in Indonesia. The second consideration came about as a result of the fact that online asynchronous learning is highly reliant on Internet access. In fact, not all regions in Indonesia have access to a reliable Internet network (Azhari and Fajri, 2021). Meanwhile, the third and fourth criteria were required as evidence of the applicant's commitment to the program and showed support from the principal. Finally, the fifth condition established that participants possess a prior understanding of linear algebra.

More than 60 teacher applicants matched the necessary criteria. However, during the process, some of the chosen participants displayed no online activity and could not be reached in any way. As a result, there were only 57 participants. 


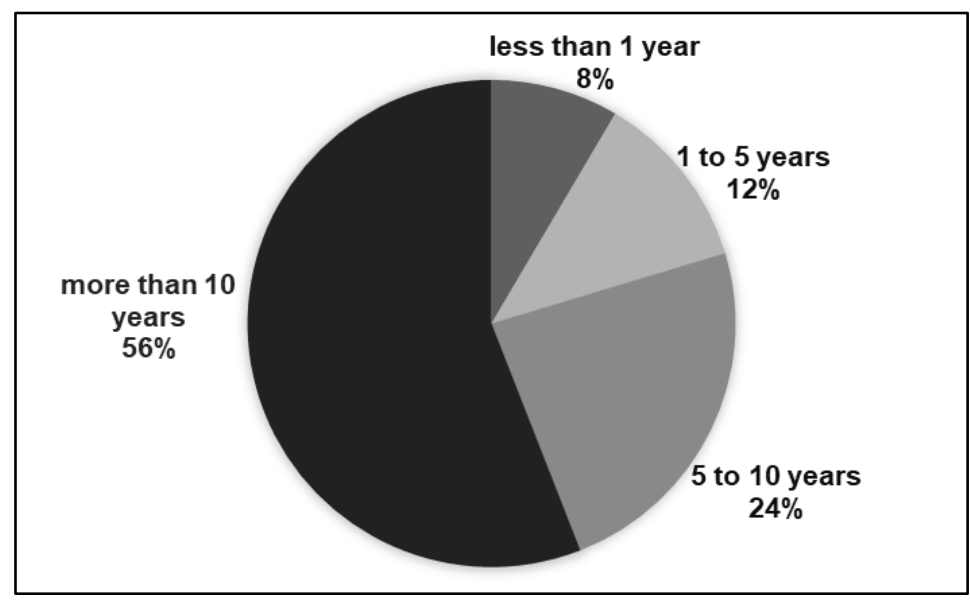

Figure 2: The years of in-service experience of the selected participants

Furthermore, the data on the years of in-service experience of the selected participants are presented in Figure 2. This information is essential to understand how long they have left mathematics scholarly knowledge in their pre-service education. As illustrated in Figure 2, more than half of the selected participants have more than ten years of teaching experience. The authors also interviewed several teachers, asking what they know about why matrix multiplication has a different procedure than matrix addition or scalar multiplication by matrix. These preliminary interviews revealed that most of them never paid attention to the rationale of matrix multiplication that they taught in high school. Yani, a high school teacher in Bantul, Indonesia, said, "I only know the matrix multiplication formula as written in the students' textbook. I just thought it is an international convention that matrix multiplication rules are different from matrix addition or scalar-matrix multiplication...".

Furthermore, the natural setting of participants' technology mastery should also be informed. This study used GeoGebra Classroom as one of the technology in the mathematics situations (which will be discussed later in the analysis of technology sub-section). As a result, information on the GeoGebra skills of the participants is necessary. The chosen participants were asked to answer one multiple choice question on a Google Form regarding how they rated their level of mastering GeoGebra. Figure 3 demonstrates that there were no participants who had never used GeoGebra. Moreover, based on their self-rated, the mastery level of GeoGebra varied and was dominated by participants with moderate GeoGebra skills levels. However, some participants were advanced or even slightly mastered GeoGebra.

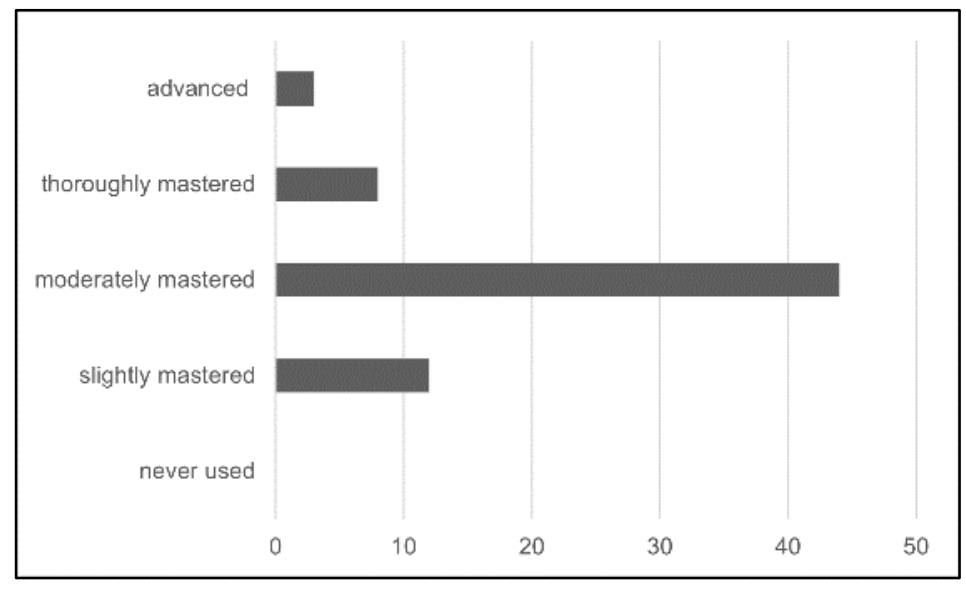

Figure 3: Participants' self-rated mastery of GeoGebra

\subsection{Data collection and data analysis}

The data was collected through a literature review on scholarly knowledge about matrix multiplication, participants' task responses, participants' responses on the forum, FGD, and phone interviews. For the confidentiality of participants' data, a numbering system prefaced with "P" was used to replace the participant's name. In capturing participant posts on the forum, participants' full names were blurred. 
Data analysis was carried out qualitatively (Miles, Huberman, and Saldana, 2014). First, the authors carefully observed the online learning situation and marked the evidence related to the research objectives. Second, the authors discussed internally to reach a consensus on which pieces of evidence should be used, which should be eliminated, and how it should be categorized. Finally, the finding is displayed and concluded. The authors acknowledge the limitations of this study that personal subjectivity and reflection strongly influence the analysis. Hence the authors used various data to triangulate the findings and minimize bias (Denzin, 2017).

\section{Results and Discussion}

In this section, the results of the analysis of the prospective learning situation, analysis of metatechnopedadidactic, and retrospective analysis will be presented. Analysis of the prospective learning situation is used to answer the first research question: How was the process of designing the online learning situation facilitate in-service mathematics teachers in lifting their external transposition knowledge of matrix multiplication. Meanwhile, analysis of meta-technopedadidactic is used to solve the second research question: how was the implementation of online learning situations facilitate in-service mathematics teachers in lifting their external transposition knowledge of matrix multiplication. Finally, the retrospective analysis means to answer the last research question: what should be improved for future implementation.

\subsection{Analysis of the prospective learning situation}

Here, the analysis of scholarly knowledge as didactic, analysis of pedagogy, and analysis of technology will be discussed. The discussion will be continued with the development of a prospective learning situation. The results of the FGD will then be presented as an external validation of the learning situation's design.

\subsubsection{Analysis of scholarly knowledge of matrix multiplication}

The concept of the matrix is one of the essential pieces of scholarly knowledge in mathematics. Matrix multiplication is a compulsory topic in Indonesia's high school curriculum (age 16-18 years old) (Ministry of Education and Culture, 2018). However, the definition of matrix multiplication in the high school curriculum is a ready-to-use concept that is abstract and procedural (Allyson Hallman-Thrasher, Erin T. Litchfield, and Kevin E. Dael, 2016; Barahmand, 2020). Matrix multiplication at the Indonesian high school level curriculum leads to the solution of a system of linear equations. On the other hand, matrix multiplication is defined in scholarly knowledge in the 18th century by Arthur Cayley (Barahmand, 2020) and then occurs in linear algebra, which can be visualized geometrically (Cook, Zazkis, and Estrup, 2018).

The analysis of scholarly knowledge was based on the study of Cook, Zazkis, and Estrup (2018) that discuss the rationale of matrix multiplication in linear algebra. Scholarly knowledge continues to develop dynamically along with technological developments so that there are more and more studies supporting the emerging technology to support the visualization of teaching matrix concepts at the tertiary level, as shown by (Aytekin and Kiymaz, 2019). At this point, the learning situation tends to facilitate teachers constructing an understanding of matrix multiplication using visualization and then providing a discussion about the transposition.

\subsubsection{Analysis of pedagogy}

Constructive learning is the pedagogical approach used in this study. The learning process begins with a triggering question, which is followed by scaffolding tasks that help learners through the action, formulation, validation, and institutionalization processes, allowing them to develop their knowledge (Brousseau, 2002). Because in-service teachers are adult learners, andragogy should be taken into account when shaping pedagogical interactions. Adult learning andragogy is concerned with respecting principles such as the learner's curiosity for information, autonomy in learning, prior experiences, preparedness, orientation, and motivation (Knowles et al., 2015).

\subsubsection{Analysis of technology}

Technological requirements in the design are centered on technology to support didactic interaction, pedagogy interaction, and didactic pedagogy anticipation. In particular, the technology is needed to facilitate participants in constructing knowledge of matrix multiplication visualizations in an online environment. Technology in mathematics learning plays two prominent roles: technology to provide a feedback environment and technology to do mathematics tasks (Joubert, 2017). Therefore the design combined Moodle as a Learning Management System (LMS) and GeoGebra Classroom as a Task Response System (TRS).

The decision was based on the following. One of the factors in the failure of online learning during the COVID19 pandemic in Indonesia is the teachers' readiness to use technology (Mulyanti, Purnama, and Pawinanto, 
2020; Azhari and Fajri, 2021). So, the choice of popular technology is fundamental in reducing TE and participants' anxiety (Price and Kadi-Hanifi, 2011). Moodle is a popular LMS technology used in mathematics teachers' PD in Indonesia. Indonesia is one of the top ten nations worldwide regarding the number of Moodle accounts (Moodle, 2021). The main features were needed are forums and pages, which are well integrated into Moodle and are adaptable (Zainuddin, Idrus, and Jamal, 2016). Moreover, numerous studies have established that Moodle-mediated learning contributed positively to the mathematics learning process (Mlotshwa, Tunjera, and Chigona, 2020; Astriawati and Pratama, 2021).

GeoGebra Classroom is a GeoGebra-based virtual classroom. GeoGebra is a popular tool in mathematics education that combines Computer Algebra System (CAS) and Dynamic Geometry Software (DGS) (Hohenwarter and Fuchs, 2005; Marfuah, 2017). GeoGebra features a special plugin to combine with Moodle (Ferdiánová, 2017). GeoGebra is also widely known to positively impact mathematics learning (Adelabu, Makgato, and Ramaligela, 2019; Martinovic and Manizade, 2020; Juandi, et al., 2021). However, GeoGebra Classroom as a new TRS developed by GeoGebra (Zöchbauer and Hohenwarter, 2020) still opens opportunities for further exploration. It allows a teacher to notice all learners' manipulation when they engage in a GeoGebra activity even though the teacher and students are not in the same room. GeoGebra Classroom allows the TE to observe participant interactions with GeoGebra, read each participant's response, and monitor participants' progress online. Additionally, participants are not required to create an account or join the GeoGebra website; instead, they just input the class code given by the TE.

\subsubsection{Prospective learning situation}

Table 1 is the learning trajectory in GeoGebra Classroom from our prospective analysis. The analysis is based on the fact that in-service teachers have already learned abstract knowledge of linear algebra in their pre-service education. The visualization is more to bridge the teacher's transposition knowledge, not narrow down the teachers' generalizations and reasoning.

Table 1: Learning trajectory in GeoGebra Classroom

\begin{tabular}{|c|c|}
\hline Chapter & Technology \\
\hline \multicolumn{2}{|l|}{ 1. A matrix is a vector in vector space } \\
\hline a. Recalling vector space definition & video, text, task 1 \\
\hline b. Vector in n-dimensional Euclid space & text \\
\hline c. Focus on 2- and 3-dimensional Euclid space & task 2 , task 3 , task 4 , task 5 \\
\hline \multicolumn{2}{|l|}{ 2. Visualization of additional vectors } \\
\hline a. Visualization in $\mathbb{R}^{2}$ & task 6, task 7 \\
\hline b. Visualization in $\mathbb{R}^{3}$ & task 8 \\
\hline 3. Visualization of scalar-vector multiplication & task 9 \\
\hline 4. Linear combination & text, task 10 \\
\hline 5. Linear transformation & text, task 11 \\
\hline \multicolumn{2}{|l|}{ 6. Matrix-vector multiplication } \\
\hline a. Visualization in 2-Dimensional & task 12, task 13 , task 14 \\
\hline b. Visualization in 3-Dimensional & task 15 , task 16 \\
\hline
\end{tabular}

Due to the COVID-19 pandemic, shifting from a face-to-face didactic system to an online environment is inevitable. The anticipation was re-situating the learning situation in an asynchronous environment. Table 2 shows the sequence of the situation of devolution, mathematics situations, and the situation of institutionalization to change the milieu from a face-to-face classroom to an online environment. Figure 4 shows the capture of our GeoGebra Classroom.

Table 2: Prospective learning situation

\begin{tabular}{ll}
\hline \multicolumn{1}{c}{ Situation } & Activity Description \\
\hline Situation of & Course Introduction \\
Devolution & - One of the introductory fragments in Moodle Page: \\
"An activity of using GeoGebra Classroom will be presented to understand \\
the visualization of matrix multiplication. If you were familiar with using \\
GeoGebra in terms of your duties as a teacher, then here, GeoGebra will be \\
used to demonstrate as you are a mathematician. Please click on the \\
following link and enter the code provided by TE. You are free to discuss \\
anything related to this visualization in the provided forum."
\end{tabular}




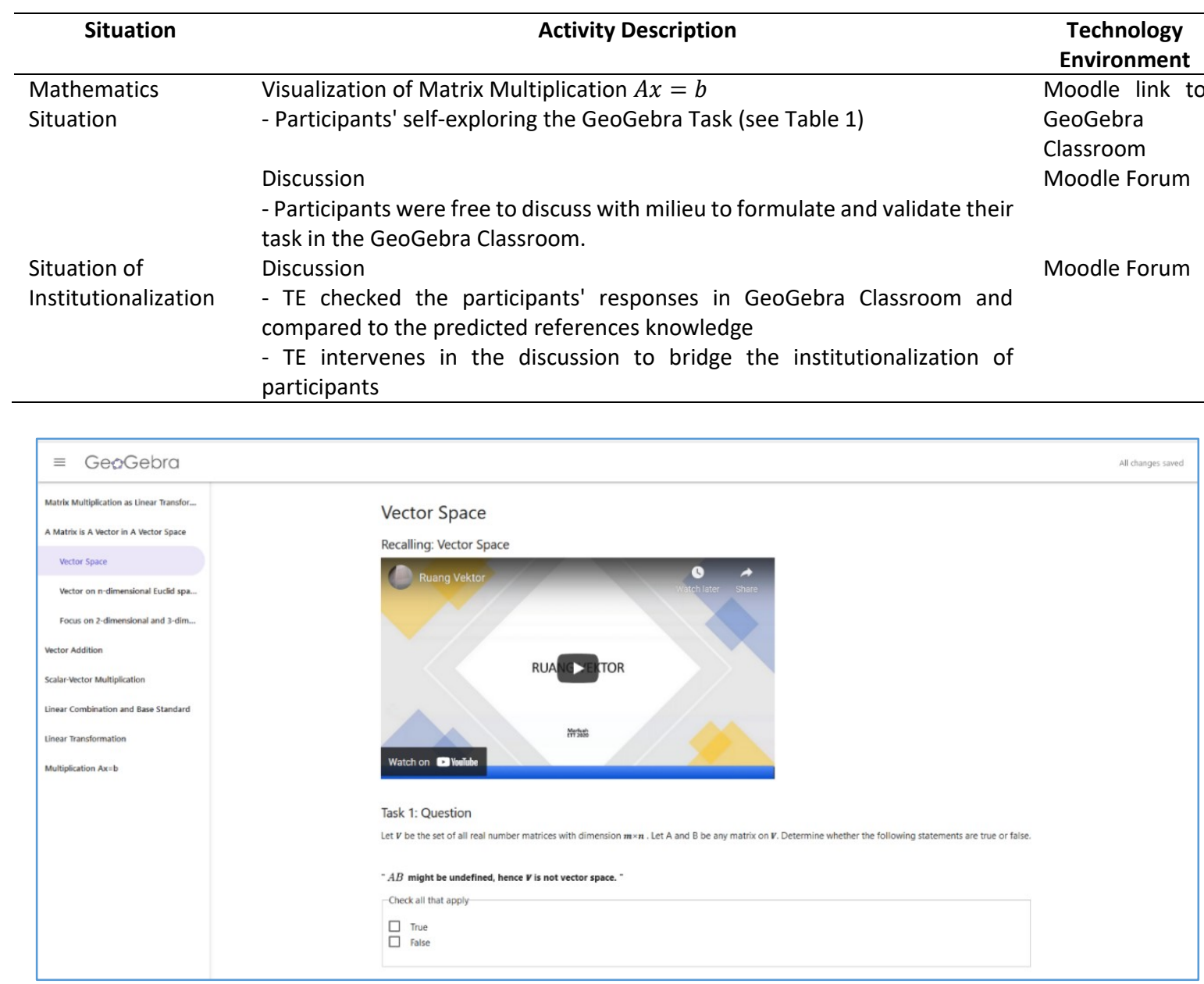

Figure 4: A capture of activity in GeoGebra Classroom (after translation)

Of the sixteen GeoGebra tasks provided, the discussion is limited to tasks 12-14 because the responses to tasks 12-14 best described how participants construct their transposition knowledge. Task 12 asks participants to respond by moving the red point to change the matrix $A$ in order to observe the visualization of matrix multiplication (Figure 5). Task 13 is a question that directs participants to visualize multiplying specifically $\left[\begin{array}{cc}0 & 3 \\ 2 & -1\end{array}\right]\left[\begin{array}{l}2 \\ 2\end{array}\right]$ using an applet in Task 12 . Task 14 is an essay question to explore participants' ideas about matrix multiplication visualization related to the matrix multiplication process in a high school way. The question of Task 14 is:

"Are the visualization results following the usual matrix multiplication calculations rules that you teach? Please elaborate your answer". 


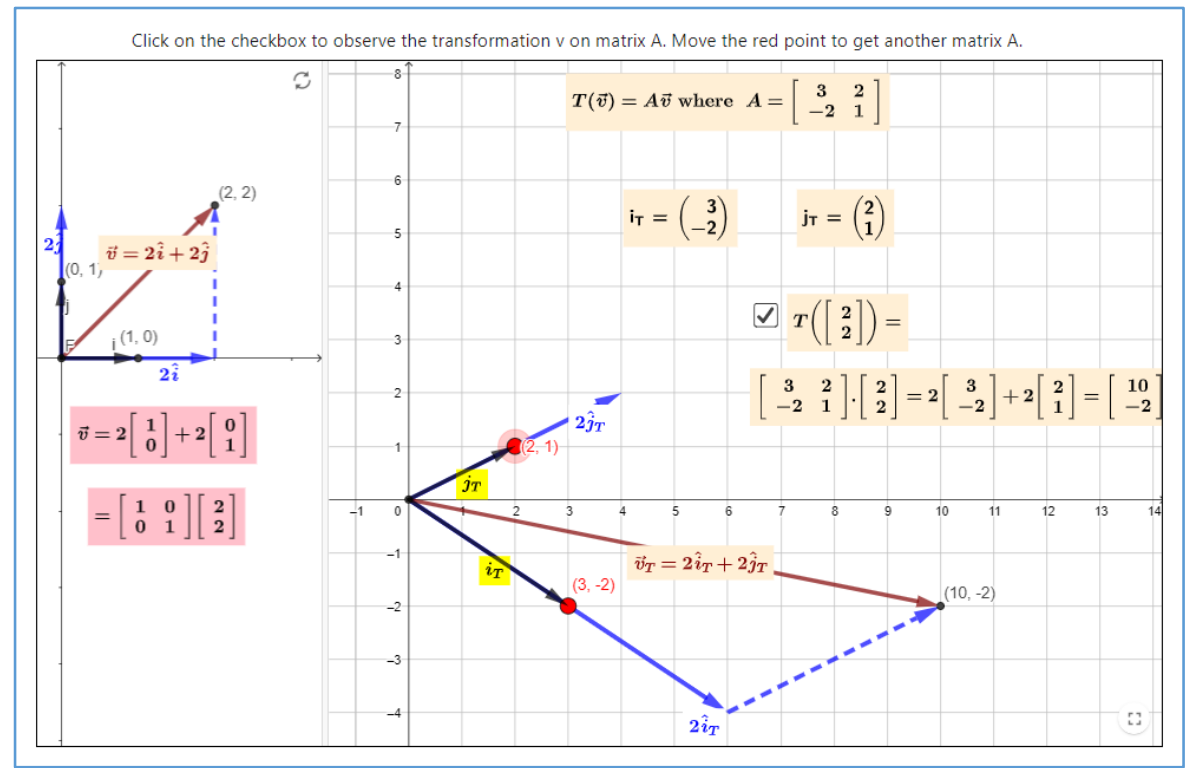

Figure 5: Task 12 in GeoGebra Classroom (after translation)

\subsubsection{FGD results}

Table 3 shows the FGD results. FGD emphasizes a research process to ensure rigor and validity (Hennink, 2014). The FGD was dominated by discussions about trajectory in the GeoGebra Classroom. Some detailed points in the instructional required improvement. Overall, the FGD participants agreed that the prospective learning situation could be implemented.

Table 1: FGD Result

\begin{tabular}{|c|c|c|}
\hline Validator & Suggestion & Revision \\
\hline $\begin{array}{l}\text { Teachers } \\
\text { Educator }\end{array}$ & - $\quad$ The time duration of the video should not be too long. & $\begin{array}{l}\text { The video length was revised to } \\
\text { less than } 3 \text { minutes. }\end{array}$ \\
\hline & $\begin{array}{l}\text { - Teachers may have forgotten the linear transformation } \\
\text { matrix. More GeoGebra exploratory activities should follow } \\
\text { the explanation of the linear transformation matrix. }\end{array}$ & $\begin{array}{l}\text { More GeoGebra activities of the } \\
\text { linear transformation matrix were } \\
\text { added. }\end{array}$ \\
\hline Teachers & $\begin{array}{l}\text { - Sliders for visualization in Task } 15 \text { should only be } \\
\text { integers because the main idea is to understand the } \\
\text { visualization, not to do complex calculations. }\end{array}$ & $\begin{array}{l}\text { The increment of the slider in } \\
\text { Task } 15 \text { was changed from } \\
\text { decimal to an integer }\end{array}$ \\
\hline
\end{tabular}

\subsection{Analysis of meta-technopedadidactic}

The second research question is answered by analyzing participants' responses in the GeoGebra task and Moodle. Participants' posts in an online asynchronous discussion can represent the level of knowledge institutionalization and the level of involvement in their learning process (Galikyan and Admiraal, 2019). The findings are categorized into the following.

\subsubsection{The role of technology as a visualization tool}

Task 14: "Are the visualization results following the usual matrix multiplication calculations rules that you teach? Please elaborate your answer".

Task 14: Question
Apakah hasil visualisasi sesuai dengan perhitungan perkalian matriks menggunakan cara yang biasa Saudara
gunakan? Jelaskan jawaban Saudara.
sama, tetapi algoritmanya beda. DI SMA Ax=B pakai aturan baris kali kolom. Dengan visualisasi saya menemukan
bisa juga pakai kombinasi linear dari kolom-kolom A. Dan bagi saya, visualisasi ini lebih mudah dipahami cara
menghitung perkalian matriks. Hanya saja harus mengingat kembali aljabar linear, yang anak SMA belum dapat.

Figure 6: $\mathrm{P} 1$ 's answer to Task 14 
P1: "The result is the same, but the algorithm is different. As for high school students, they use matrix multiplication by multiplying rows by columns. Meanwhile, using visualization, I found that matrix multiplication can also be a linear combination of the columns in A. Moreover, for me, this visualization is easier to understand. It is just that I have to recall linear algebra. Furthermore, high school students have not studied linear algebra yet."

By conducting interviews, we were able to triangulate the answers of $\mathrm{P} 1$ as below.

"I have been an in-service teacher for 15 years. When I studied linear algebra, I did not know GeoGebra, let alone GeoGebra Classroom. Visualization using GeoGebra reminded me of the connection between matrices and vectors. Maybe I just forgot this connection. I teach both topics (matrix and vector) in high school. However, I have always thought that matrices are algebra and vectors are geometry. Using GeoGebra makes me clearly understand the rationale of matrix multiplication that I teach. It adds to my personal knowledge."

P1's responses in Figure 6 showed that visualization helps learners concretize mathematical objects and make generalizations (Harel, 2017). This result reflects those of Arcavi (2003), who also find that visualization helps learners re-engage conceptual foundations that formal solutions can easily cover. Visualization combined with other teaching strategies has been effective in helping students understand matrix concepts (Harel, 2019). This finding also shows that GeoGebra Classroom's role in online asynchronous situations provides didactical interaction between learners and mathematics content. Furthermore, the GeoGebra Classroom facilitates selfconstructive learning in the provided learning situations. The use of technology to support visualization in learning is also proven by Stevenson et al. (2015), can create meaningful and learner-centered learning.

\subsubsection{Evidence of participants' external transpositions}

The question of Task 14 was repeated in the Moodle Forum to reinforce the discussion. The TE's question in Moodle Forum was,

"Explain your perspective about matrix multiplication visualization related to matrix multiplication that you taught according to the curriculum?"

The authors conclude three categories of evidence of learners' external transposition knowledge. First, there was an acknowledgment of the limitedness of using visualization in matrix multiplication (Figure 7). Second, there was a difference of opinion about whether this visualization could be delivered to high school students (Figure 8). And third, attention to the multiplication of $A x=0$ for $x \neq 0$ (Figure 9).

In Figure 7, Astri's institutionalization came to the conclusion that visualization is limited to the matrix of $2 \times 2$ or $3 \times 3$ dimensions. Astri's opinion is in line with Harel (2019) that visualization can limit the students' ability at the tertiary level to generalize matrix concepts. Here external transposition knowledge brought Astri to a broader understanding of how the curriculum selects and presents scholarly knowledge (Chevallard, 2019).

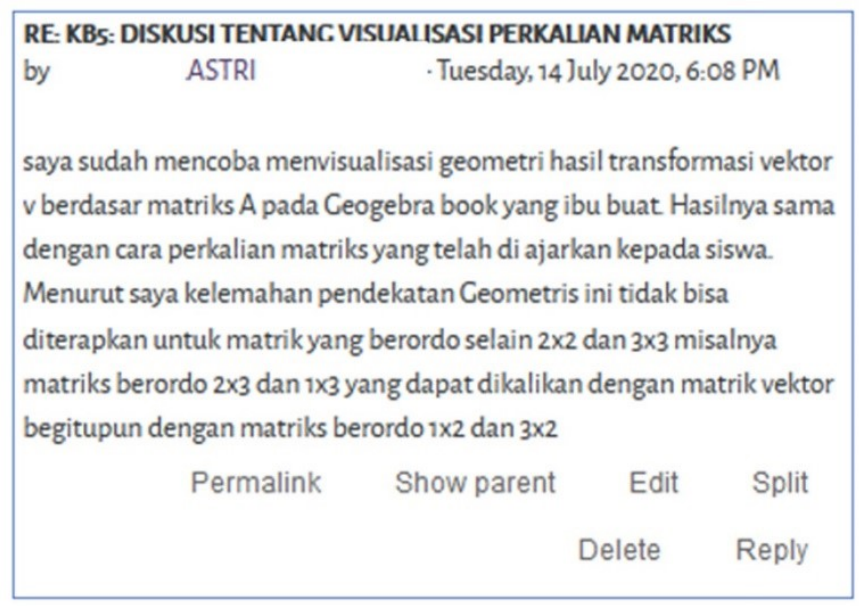

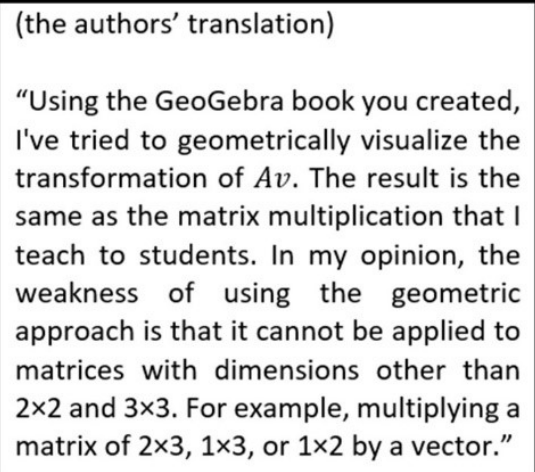

Figure 7: Astri's statement about the limitation of visualization

In Figure 8, Sari and Rahi differ in opinion about how visualization can be introduced to high school students. Sari argued that the prerequisite for understanding the visualization of matrix multiplication lies in students' 
recognition of object position in 2-dimensional and 3-dimensional space. So, according to Sari, as long as students master these prerequisites, visualization can be delivered. Meanwhile, Rahi argued that students should have learned vector concepts to understand visualization. However, in the Indonesian high school curriculum, the vector topic is non-compulsory. Hence, the visualization approach cannot be delivered to all students. Rahi also emphasized the formidable challenge of introducing the concept of linear algebra to high school students.

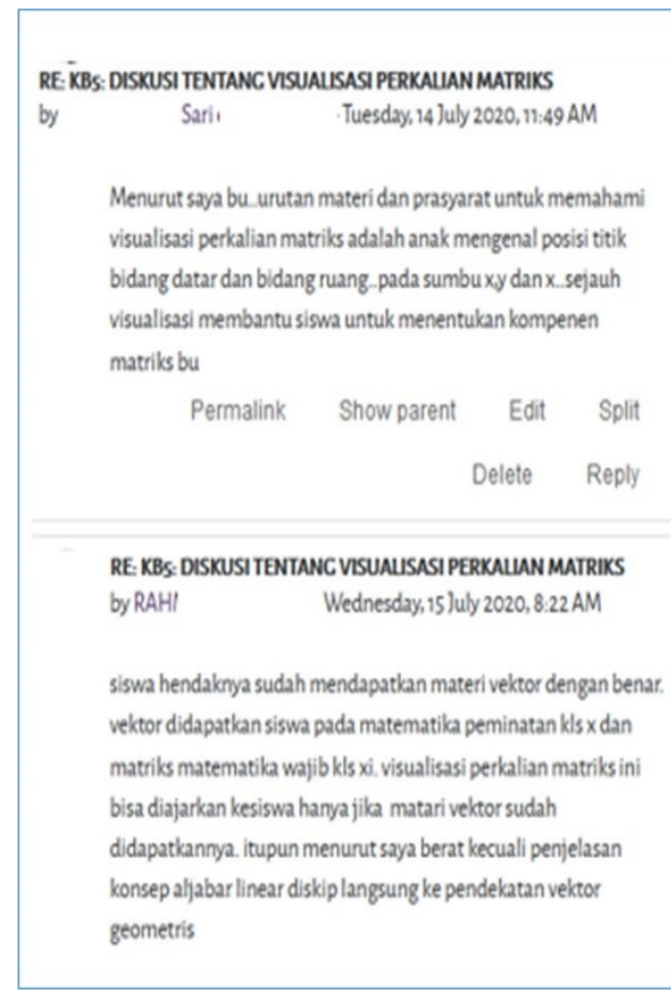

(the authors' translation)

Sari: "I think the prerequisites in understanding

visualization of matrix multiplication lies in

understanding object position on 2- or 3-

dimensional space. As long as students master

these prerequisites, visualization can be

delivered."

Rahi: "Students should have learned vector concepts to understand visualization. But, the vector topic is non-compulsory (in the Indonesian high school curriculum). So, the visualization approach cannot be delivered to all students. I think introducing linear algebra to high school students is quite a challenge unless the concept of linear algebra is omitted and the geometry visualization explanation is given first."

Figure 8: Difference of opinion of Sari and Rahi

As triangulation, Sari's opinion arose because of the experience as a mathematics teacher in a science specialization high school, in which all students have studied vector topics. Meanwhile, Rahi's opinion reveals obstacles in the structure of the Indonesian curriculum so that it is impossible to teach matrix multiplication using visualization. Rahi was aware of the didactical obstacle of matrix topic at the high school level. A didactical obstacle is a learning barrier that emerges from the curriculum structure (Brousseau, 2002). Further research is needed to determine how this awareness can inspire teachers to anticipate students' learning obstacles.

Figure 9 shows another evidence of external knowledge transposition. The TE intervened in the situation by asking in the forum:

"Have you observed the visualization of $A x=0$ ? Tell me your finding."

Here TE played a role in linking teachers' scholarly knowledge to the curriculum. In the situation of institutionalization here, TE used Moodle and GeoGebra Classroom simultaneously to intervene to complete knowledge links that have not been covered in previous mathematics situations. 


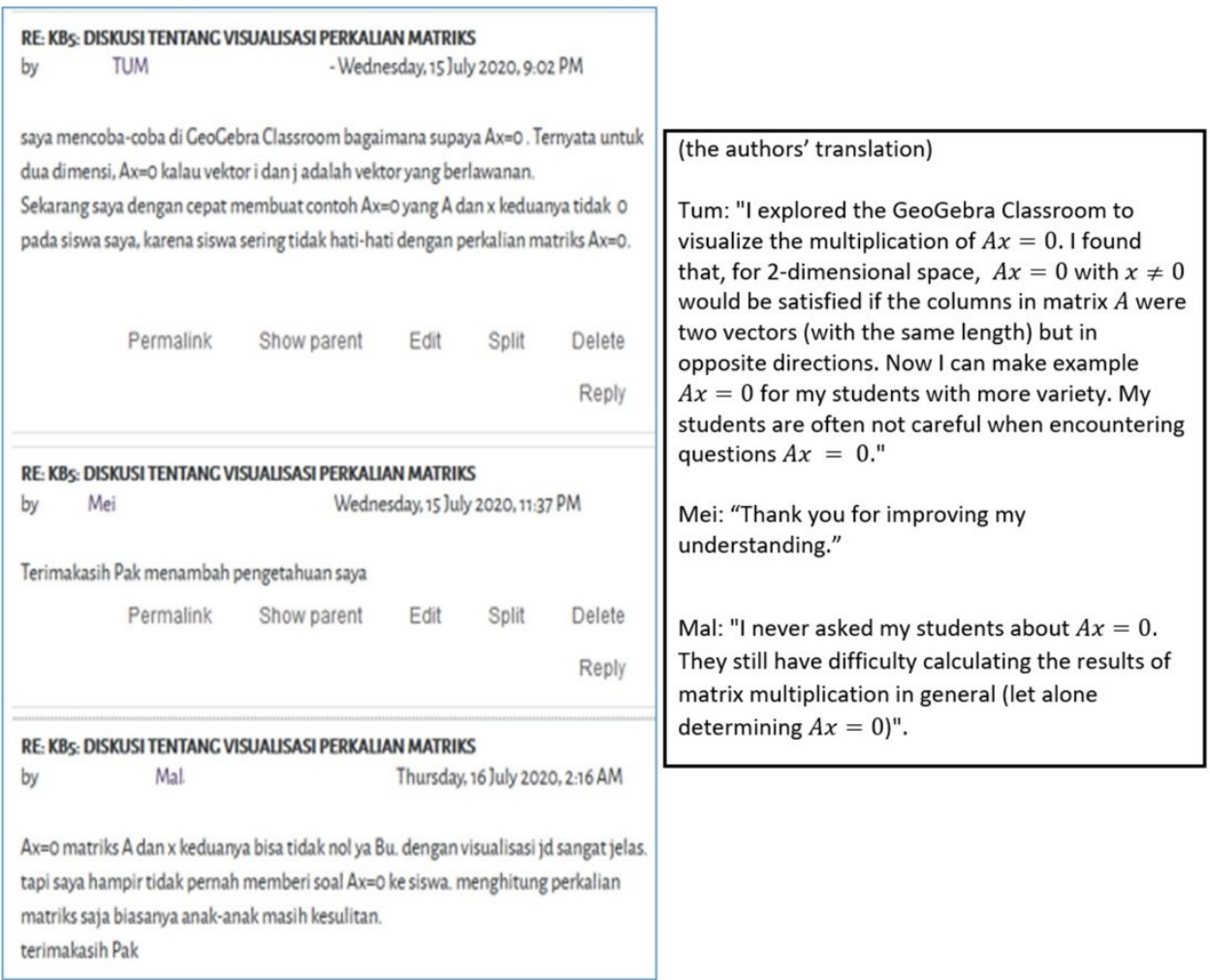

Figure 9: Discussion about $A x=0$

Mal's statement is consistent with Cook's (2018) that teachers frequently overlook the importance of reinforcing students' understanding of the zero-product property. High school students already have a lot of mathematics knowledge in their mathematics experience. However, the matrix is the first mathematical object in their cognitive structure where multiplication is not commutative, and the zero-product property is different from the multiplication of real numbers. The discussion above also shows that the providing learning situation facilitated learners to build their external transposition knowledge about $A x=0$. These results also support the idea of Wasserman (2018) that institutionalizing advanced mathematical knowledge can help teachers build ways of thinking about mathematics practice in schools. Moreover, it also raises the reflection of teachers' internal transposition in the classroom. As Kynigos and Kalogeria (2012) state, online learning provides a communication medium for teachers to express mathematical ideas and share their pedagogical experiences.

\subsubsection{Technology as constraints but also collaboration tool in the learning situations}

Technology was also the main constraint that hindered the participants' institutionalization. The finding shows that some participants had difficulty doing Task 13 and expressed it in the Moodle discussion forum. Here is one fragment of Moodle forum discussion.

P2: "Please guide me on how to answer this question (P2 captured Task 13). I do not know how to visualize."

P3: "me too...."

P5: "Go to Task 12 first. Then,

1. Move i to $[0,2]$ using redpoint;

2. Move j to $[3,-1]$ using redpoint;

3. Please look at what happens when you make changes, focussing on the matrix multiplication form displayed as text."

P2: "Thanks."

P4: "Thanks for the explanation. Now I have a little idea too."

After observing P2, P3, and P4's responses in GeoGebra Classroom, they managed to complete all tasks as predicted. This finding shows that the anticipation of providing a discussion forum on online asynchronous situations plays a vital role in pedagogy interaction and didactic interaction (Galikyan and Admiraal, 2019). Participant P2 could not start the Mathematical Situation because they were not clear about the given rules in the Situation of Devolution. Nevertheless, they took the initiative to ask milieu for help in the discussion forum (and it turned out that P3 and P4 experienced the same situation). Here, the technology served as a collaboration tool between learners as they interact in solving a problem. 


\subsection{Retrospective analysis}

Another finding was that twelve participants (around 21\%) jumped Tasks 12, 13, and 14 in the GeoGebra Classroom. Consequently, there was no evidence of their institutionalization process. The authors observed the discussion forum and triangulated it with phone interviews. Participants who did not complete all the tasks were questioned about their reasons and difficulties. The reasons for incompleteness tasks were categorized as 1 ) time management, 2) being hesitant to ask questions in the forum, and 3) only focused on Moodle activity completion. This finding is not surprising as many authors mention the disadvantages of asynchronous online learning: participants tend to neglect tasks completion (Galikyan and Admiraal, 2019; Lamanauskas and Makarskaitè-Petkevičienè, 2021). Despite the fact that the participants were previously set to voluntary registration, acknowledging not anticipating this finding should be delivered as the main retrospective of the learning situations.

As a retrospective analysis, the authors noted some anticipations for future improvement. First, the authors see the need to strengthen participants' understanding of the GeoGebra environment to minimize technology issues. Providing introductory workshops can be a great way to shape participants' technological readiness (Pölzl-Stefanec, 2021). Second, the TE should encourage participants to be more active in discussing asynchronously in Moodle, considering the critical role of discussion forums in all learning situations. "Students need to be made aware of potential knowledge construction benefits of discussion forums in order not to view contributions to online discussions as something extra ...." (Galikyan and Admiraal, 2019, p. 7). Finally, the authors see the need to provide real-time communication in facilitating pedagogy interaction and didactic interaction, such as social media. A learning management system supported by interactive communication technology through social media encourages learners to actively participate in the learning process (Chaka, Nkhobo, and Lephalala, 2020). Further research must devise practical strategies for increasing learner engagement in online learning without limiting teachers' autonomy as adult learners.

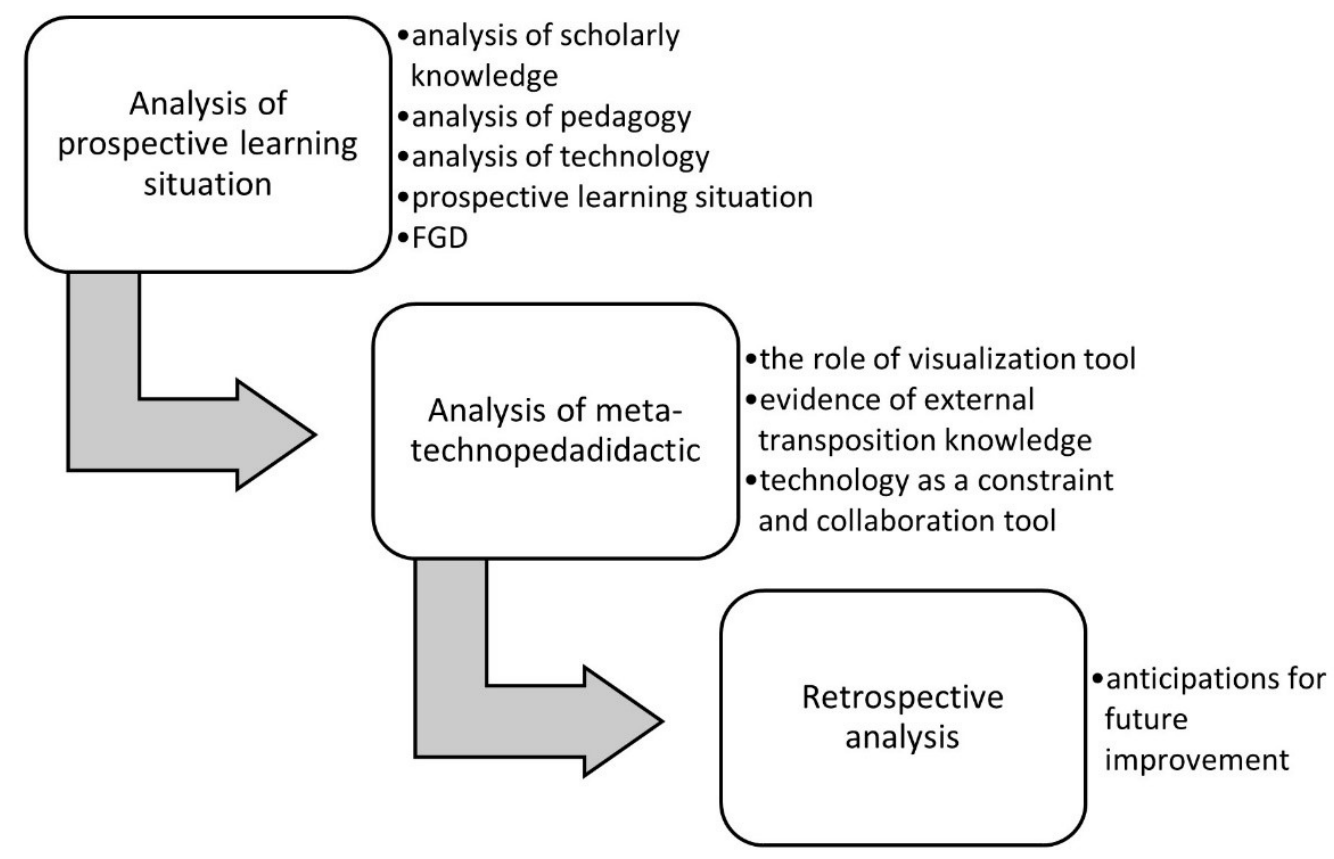

Figure 10: The findings in this study

\section{Conclusion}

This study describes the process of providing online learning situations in facilitating the in-service mathematics teachers lifting their external transposition knowledge of matrices multiplication during the COVID-19 pandemic. As shown in Figure 10, the process began with an analysis of prospective learning situations, followed by an analysis of meta-technopedadidactic, then a retrospective analysis. In the analysis of prospective learning situations, we developed our reference epistemology knowledge and pedagogical analysis. We then designed a learning trajectory and anticipation involving technology. The design of the learning situation combined Moodle as a feedback environment and GeoGebra Classroom as a task responses system. Focus Group Discussion was conducted to ensure the validity of the prospective learning situation. The meta-technopedadidactic analysis displayed the role of visualization using technology in didactic and pedagogy interaction. It also revealed 
evidence of how learning situations can promote or hinder learning. Finally, the retrospective analysis suggested some improvements for future learning. Although the learning situation in this study is specifically related to the socio-cultural of educational institutions in Indonesia, the findings have the potential to be an asset for the longterm sustainability of e-learning for teachers' professional development programs, particularly those aimed at improving specific subject-matter knowledge, in mathematics or beyond. Further research is needed on how mathematics teachers' professional development provides e-learning to lift the internal transposition knowledge of the teachers.

\section{Acknowledgment}

We thank the anonymous reviewers for their great feedback in improving our work. We also appreciate all of the teacher participants, widyaiswara participants, and ETT teams of PPPPTK Matematika for contributing to our research. Gratitude is also sent to Lembaga Pengelola Dana Pendidikan (LPDP) for funding our study.

\section{References}

Adelabu, F.M., Makgato, M., and Ramaligela, M.S., 2019. The importance of dynamic geometry computer software on learners' performance in geometry. Electronic Journal of e-Learning, 17(1), pp. 52-63.

Allyson Hallman-Thrasher, Erin T. Litchfield, and Kevin E. Dael, 2016. Original recipes for matrix multiplication. The Mathematics Teacher, 110(3), pp. 182-190. https://doi.org/10.5951/mathteacher.110.3.0182.

Arcavi, A., 2003. The role of visual representations in the learning of mathematics. Educational Studies in Mathematics, 52(3), pp. 215-241. https://doi.org/10.1023/A:1024312321077.

Astriawati, N. and Pratama, H.A., 2021. Cadets ' effectivity and perception on Moodle online learning in economy mathematics course. In: Advances in Social Science, Education and Humanities Research. Atlantis Press SARL, pp. 3439.

Aytekin, C. and Kiymaz, Y., 2019. Teaching linear algebra supported by GeoGebra visualization environment. Acta Didactica Napocensia, 12(2), pp. 75-96. https://doi.org/10.24193/adn.12.2.7.

Azhari, B. and Fajri, I., 2021. Distance learning during the COVID-19 pandemic: School closure in Indonesia. International Journal of Mathematical Education in Science and Technology. https://doi.org/10.1080/0020739X.2021.1875072.

Barahmand, A., 2020. On the definition of matrix multiplication. International Journal of Mathematical Education in Science and Technology, 51(7), pp. 1137-1145. https://doi.org/10.1080/0020739X.2019.1699179.

Basitere, M. and Ivala, E., 2015. Mitigating the mathematical knowledge gap between high school and first year university chemical engineering mathematics course. Electronic Journal of e-Learning, 13(2), pp. 68-83.

Bosch, M., Hausberger, T., Hochmuth, R., Kondratieva, M., and Winsløw, C., 2021. External didactic transposition in undergraduate mathematics. International Journal of Research in Undergraduate Mathematics Education, 7(1), pp. 140-162. https://doi.org/10.1007/s40753-020-00132-7.

Brousseau, G., 2002. Theory of Didactical Situations in Mathematics. Edited and translated by N. Balacheff et al. Kluwer Academic Publishers.

Brousseau, G. and Warfield, V., 2020. Didactical Situations in Mathematics Education. In: S. Lerman, ed. Encyclopedia of Mathematics Education. 2nd edition. Springer, pp. 206-213.

Cao, Y., Zhang, S., Chan, M.C.E., and Kang, Y., 2021. Post-pandemic reflections: Lessons from Chinese mathematics teachers about online mathematics instruction. Asia Pacific Education Review, 22, pp. 157-168. https://doi.org/10.1007/s12564-021-09694-w.

Chaka, C., Nkhobo, T., and Lephalala, M., 2020. Leveraging MoyaMA, Whatsapp and online discussion forum to support students at an open and distance e-learning university. Electronic Journal of e-Learning, 18(6), pp. 494-515. https://doi.org/10.34190/JEL.18.6.003.

Chevallard, Y., 2019. Introducing the anthropological theory of the didactic: An attempt at a principled approach. Hiroshima Journal of Mathematics Education, 12, pp. 71-114.

Chevallard, Y. and Bosch, M., 2020. Didactic transposition in mathematics education. In: Stephen Lerman, ed. Encyclopedia of Mathematics Education: 2nd edition. London: Springer, pp. 214-218.

Cook, J.P., 2018. An investigation of an undergraduate student's reasoning with zero-divisors and the zero-product property. Journal of Mathematical Behavior, 49, pp. 95-115. https://doi.org/10.1016/j.jmathb.2017.11.001.

Cook, J.P., Zazkis, D., and Estrup, A., 2018. Rationale for matrix multiplication in linear algebra textbooks. In: S. Stewart, C. Andrews-Larson, A. Berman and M. Zandieh, ed. Challenges and Strategies in Teaching Linear Algebra (ICME-13 Monographs). Switzerland: Springer International Publishing, pp. 103-125. https://doi.org/10.1007/978-3-31966811-6_5.

Corfman, T. and Beck, D., 2019. Case study of creativity in asynchronous online discussions. International Journal of Educational Technology in Higher Education, 16(22). https://doi.org/10.1186/s41239-019-0150-5.

Creswell, J.W. and Creswell, J.D., 2018. Research Design: Qualitative, Quantitative and Mixed Methods Approaches. 5th edition. SAGE.

Denzin, N.K., 2017. The Research Act: A Theoretical Introduction to Sociological Methods. New York: Routledge.

Dreher, A., Lindmeier, A., Heinze, A., and Niemand, C., 2018. What kind of content knowledge do secondary mathematics teachers need?: A conceptualization taking into account academic and school mathematics. Journal fur MathematikDidaktik, 39(2), pp. 319-341. https://doi.org/10.1007/s13138-018-0127-2. 
Fauzi, A., Wandira, R., Sepri, D., and Hafid, A., 2021. Exploring students' acceptance of Google Classroom during the Covid19 pandemic by using the technology acceptance model in West Sumatera Universities. The Electronic Journal of eLearning, 19(4), pp. 233-240. https://doi.org/10.34190/ejel.19.4.2348.

Ferdiánová, V., 2017. GeoGebra materials for LMS Moodle focused Monge on projection. Electronic Journal of e-Learning, 15(3), pp. 259-268.

Fuadiah, N.F., Suryadi, D., and Turmudi, 2019. Teaching and learning activities in classroom and their impact on student misunderstanding: A case study on negative integers. International Journal of Instruction, 12(1), pp. 407-424. https://doi.org/10.29333/iji.2019.12127a.

Galikyan, I. and Admiraal, W., 2019. Students' engagement in asynchronous online discussion: The relationship between cognitive presence, learner prominence, and academic performance. The Internet and Higher Education, 43. https://doi.org/10.1016/j.iheduc.2019.100692.

Garad, A., Al-Ansi, A.M., and Qamari, I.N., 2021. The role of e-learning infrastructure and cognitive competence in distance learning effectiveness during the COVID-19 pandemic. Cakrawala Pendidikan, 40(1), pp. 81-91. https://doi.org/10.21831/cp.v40i1.33474.

Gómez-Blancarte, A., Romo-Vázquez, A., Miranda, I., Aguilar, M.S., Castañeda, A., and Lezama, J., 2019. An online learning community for the professional development of mathematics teachers in Mexico. Interciencia, 44(4), pp. $247-252$. Available at: https://www.redalyc.org/articulo.oa?id=33959119010.

Guba, E.G. and Lincoln, Y.S., 2005. Paradigmatic controversies, contradictions, and emerging confluences. In: N.K. Denzin and Y.S. Lincoln, ed. The SAGE Handbook of Qualitative Research. 3rd edition. SAGE, pp. 191-216.

Harel, G., 2017. The learning and teaching of linear algebra: Observations and generalizations. Journal of Mathematical Behavior, 46, pp. 69-95. https://doi.org/10.1016/j.jmathb.2017.02.007.

Harel, G., 2019. Varieties in the use of geometry in the teaching of linear algebra. ZDM Mathematics Education, 51(7), pp. 1031-1042. https://doi.org/10.1007/s11858-018-01015-7.

Hennink, M.M., 2014. Focus Group Discussions. Oxford University Press.

Herbst, P. and Chazan, D., 2020. Mathematics teaching has its own imperatives: Mathematical practice and the work of mathematics instruction. ZDM Mathematics Education, 52(6), pp. 1149-1162. https://doi.org/10.1007/s11858-02001157-7.

Hohenwarter, M. and Fuchs, K., 2005. Combination of dynamic geometry, algebra and calculus in the software system GeoGebra. In: Computer Algebra Systems and Dynamic Geometry Systems in Mathematics Teaching Conference 2004.

Joubert, J., Callaghan, R., and Engelbrecht, J., 2020. Lesson study in a blended approach to support isolated teachers in teaching with technology. ZDM Mathematics Education, 52, pp. 907-925. https://doi.org/10.1007/s11858-02001161-x.

Joubert, M., 2017. Revisiting theory for the design of tasks: Special considerations for digital environments. In: A. Leung and A. Baccaglini-Frank, ed. Digital Technologies in Designing Mathematics Education Tasks: Potential and Pitfalls. Springer International Publishing Switzerland, pp. 17-40. https://doi.org/10.1007/978-3-319-43423-0_2.

Juandi, D., Kusumah, Y.S., Tamur, M., Perbowo, K.S., and Wijaya, T.T., 2021. A meta-analysis of Geogebra software decade of assisted mathematics learning: what to learn and where to go? Heliyon, 7(5), p. e06953. https://doi.org/10.1016/j.heliyon.2021.e06953.

Kansanen, P., 2003. Studying - The realistic bridge between instruction and learning. An attempt to a conceptual whole of the teaching-studying-learning process. Educational Studies, 29(2-3), pp. 221-232. https://doi.org/10.1080/03055690303279.

Kilpatrick, J., 2019. A double discontinuity and a triple approach: Felix Klein's perspective on mathematics teacher education. In: H.-G. Weigand, W. McCallum, M. Menghini, M. Neubrand and G. Schubring, ed. The Legacy of Felix Klein. ICME-13 Monographs. https://doi.org/10.1007/978-3-319-99386-7_15.

Koutsabasis, P., Stavrakis, M., Spyrou, T., and Darzentas, J., 2011. Perceived impact of asynchronous E-learning after longterm use: Implications for design and development. International Journal of Human-Computer Interaction, 27(2), pp. 191-213. https://doi.org/10.1080/10447318.2011.537206.

Kusumah, Y.S. and Nurhasanah, F., 2017. The endless long-term program of mathematics teacher professional development in Indonesia. In: B. Kaur, O.N. Kwon and Y.H. Leong, ed. Professional Development of Mathematics Teachers: An Asian Perspective. Springer, pp. 33-45. https://doi.org/10.1007/978-981-10-2598-3_3.

Kynigos, C. and Kalogeria, E., 2012. Boundary crossing through in-service online mathematics teacher education: The case of scenarios and half-baked microworlds. ZDM Mathematics Education, 44(6), pp. 733-745. https://doi.org/10.1007/s11858-012-0455-5.

Lamanauskas, V. and Makarskaitè-Petkevičienè, R., 2021. Distance lectures in university studies: Advantages, disadvantages, improvement. Contemporary Educational Technology, 13(3). https://doi.org/10.30935/cedtech/10887.

Mailizar, M., Almanthari, A., Maulina, S., and Bruce, S., 2020. Secondary school mathematics teachers ' views on e-learning implementation barriers during the Covid-19 pandemic: The case of Indonesia. EURASIA Journal of Mathematics, Science and Technology Education, 16(7). https://doi.org/10.29333/ejmste/8240.

Marfuah, M., 2017. Profiling self-regulated learning in online mathematics teacher training: A case study of a GeoGebra course. Southeast Asian Mathematics Education Journal, 7(1), pp. 45-55. https://doi.org/10.46517/seamej.v7i1.44. 
Martínez, S., Guíñez, F., Zamora, R., Bustos, S., and Rodríguez, B., 2020. On the instructional model of a blended learning program for developing mathematical knowledge for teaching. ZDM Mathematics Education, 52, pp. 877-891. https://doi.org/10.1007/s11858-020-01152-y.

Martinovic, D. and Manizade, A.G., 2020. Teachers using GeoGebra to visualize and verify conjectures about trapezoids. Canadian Journal of Science, Mathematics and Technology Education, 20(3), pp. 485-503. https://doi.org/10.1007/s42330-020-00103-9.

Miles, M.B., Huberman, A.M., and Saldana, J., 2014. Qualitative Data Analysis: A Methods Sourcebook. 3rd edition. Sage Publications.

Ministry of Education and Culture, 2018. Kompetensi Inti dan Kompetensi Dasar Pelajaran pada Kurikulum 2013. Available at: https://jdih.kemdikbud.go.id/arsip/Permendikbud Nomor 37 Tahun 2018.pdf [Accessed: 30 March 2020].

Mlotshwa, N., Tunjera, N., and Chigona, A., 2020. Integration of MOODLE into the classroom for better conceptual understanding of functions in Mathematics. South African Journal of Education, 40(3), pp. 1-14. https://doi.org/10.15700/10.15700/saje.v40n3a1570.

Moodle, 2021. Statistics. Available at: https://stats.moodle.org/ [Accessed: 18 June 2021].

Mulyanti, B., Purnama, W., and Pawinanto, R.E., 2020. Distance learning in vocational high schools during the COVID-19 pandemic in West Java Province, Indonesia. Indonesian Journal of Science and Technology, 5(2), pp. 271-282. https://doi.org/10.17509/ijost.v5i2.24640.

Pölzl-Stefanec, E., 2021. Challenges and barriers to Austrian early childhood educators' participation in online professional development programmes. British Journal of Educational Technology, pp. 1-17. https://doi.org/10.1111/bjet.13124.

Price, F. and Kadi-Hanifi, K., 2011. E-motivation! the role of popular technology in student motivation and retention. Research in Post-Compulsory Education, 16(2), pp. 173-187. https://doi.org/10.1080/13596748.2011.575278.

Reijers, W. and Coeckelbergh, M., 2020. Narrative and Technology Ethics. Springer Nature Switzerland AG. https://doi.org/10.1007/978-3-030-60272-7.

Ricoeur, P., 2016. Hermeneutics and The Human Sciences. 4th edition. Edited and translated by J.B. Thompson. Cambridge University Press.

Rudi, R., Suryadi, D., and Rosjanuardi, R., 2020. Teachers ' perception as a crucial component in the design of didactical design research-based teacher professional learning community in Indonesia. European Online Journal of Natural and Social Sciences, 9(3), pp. 642-654.

Ruthven, K., 2012. The didactical tetrahedron as a heuristic for analysing the incorporation of digital technologies into classroom practice in support of investigative approaches to teaching mathematics. ZDM Mathematics Education, 44, pp. 627-640. https://doi.org/10.1007/s11858-011-0376-8.

Schoenfeld, A.H., 2012. Problematizing the didactic triangle. ZDM Mathematics Education, 44, pp. 587-599. https://doi.org/10.1007/s11858-012-0395-0.

Stevenson, M., Hedberg, J., Highfield, K., and Diao, M., 2015. Visualizing solutions: Apps as cognitive stepping-stones in the learning process. Electronic Journal of e-Learning, 13(5), pp. 366-379. Available at: https://academicpublishing.org/index.php/ejel/article/view/1939.

Sumaryanta, Mardapi, D., Sugiman, and Herawan, T., 2018. Assessing teacher competence and its follow-up to support professional development sustainability. Journal of Teacher Education for Sustainability, 20(1), pp. 106-123. https://doi.org/10.2478/jtes-2018-0007.

Suryadi, D., 2013. Didactical Design Research (DDR) dalam pengembangan pembelajaran matematika. Prosiding Seminar Nasional Matematika dan Pendidikan Matematika, 1, pp. 3-12. Available at: http://aresearch.upi.edu/operator/upload/pros_ui-uitm_2011_didi_didactical_design_research.pdf.

Suryadi, D., 2019. Landasan Filosofis Penelitian Desain Didaktis (DDR). Bandung: Pusat Pengembangan DDR Indonesia.

Turmudi, T., Kusumah, Y.S., Juandi, D., and Mulyana, E., 2014. Development of didactical design of mathematics pedagogy through professional program of mathematics teacher education. Jurnal Pendidikan dan Pembelajaran, 21(1), pp. 1023. Available at: http://journal.um.ac.id/index.php/pendidikan-dan-pembelajaran/article/view/4518/987 [Accessed: 26 February 2021].

UNESCO, 2020. Education in a post covid world: Nine ideas for public action international commission on the futures of education. Available at: https://en.unesco.org/sites/default/files/education_in_a_post-covid_worldnine_ideas_for_public_action.pdf [Accessed: 30 June 2021].

Wasserman, N.H., 2018. Exploring advanced mathematics courses and content for secondary mathematics teachers. In: N.H. Wasserman, ed. Connecting Abstract Algebra to Secondary Mathematics, for Secondary Mathematics Teachers. New York: Springer, pp. 1-15. https://doi.org/10.1007/978-3-319-99214-3_1.

Zainuddin, N., Idrus, R., and Jamal, A.F.M., 2016. Moodle as an ODL teaching tool: A perspective of students and academics. Electronic Journal of e-Learning, 14(4), pp. 282-290.

Zöchbauer, J. and Hohenwarter, M., 2020. Developing a collaboration tool to give every student a voice in a classroom discussion. In: Seventh ERME Topic Conference on Language in the Mathematics Classroom, pp. 195-202. 